\title{
International Conflict and the Tenure of Leaders: Is War Still Ex Post Inefficient?
}

\author{
Giacomo Chiozza Duke University \\ H. E. Goemans University of Rochester
}

\begin{abstract}
Recent work in comparative politics and international relations has shown a marked shift toward leaders as the theoretical unit of analysis. In most of the new theoretical models a core assumption is that leaders act to stay in power. There exists, however, remarkably little systematic empirical knowledge about the factors that affect the tenure of leaders. To provide a baseline of empirical results we explore how a broad range of domestic and international factors affects the tenure of leaders. We focus in particular on the effect of conflict and its outcome. We find that political institutions fundamentally mediate the costs and benefits of international conflict and that war is not necessarily ex post inefficient for leaders. This suggests that the assumption that war is ex post inefficient for unitary rational actors can not be simply extended to leaders. Therefore, a focus on leaders may yield important new rationalist explanations for war.
\end{abstract}

W hen testing theories, researchers would like the theoretical and empirical units of analysis to match. In international relations, however, this is often not the case. On the one hand, neo-realists and others who focus on the system as their unit of analysis as well as scholars who base their theories on the unitary rational actor assumption usually rely on the statements and memoirs of leaders in their empirical research (Copeland 2000). Whereas their theoretical unit of analysis is the system or the state as a unitary rational actor, their empirical unit of analysis is the leader. On the other hand, scholars of diversionary war and, recently, the democratic peace employ leaders as their theoretical unit of analysis. In their statistical research, however, these scholars tend to rely on the country or country-year as the empirical unit of analysis (Gelpi 1997; Leeds and Davis 1997; Reiter and Stam 2002). Such mismatches between the theoretical and empirical unit of analysis can significantly weaken empirical tests and produce faulty inferences. A fundamental hurdle for scholars who focus on leaders as their theoretical unit of analysis has been the lack of appropriate data on leaders. To enable these scholars to test theories on the appropriate empirical unit of analysis and to promote further theoretical work on the role of leaders in international and comparative politics, we introduce a new data set of all leaders between 1919 and 1999.

Recent work in international relations and comparative politics attempts to build powerful new theories on a solid methodologically individualist basis by focusing on the incentives and constraints of leaders (Bueno de Mesquita et al. 2003; Cheibub and Przeworksi 1999). A central assumption in much of this new research is that leaders act to stay in power (Downs 1957). Very little is empirically known, however, about the factors that affect the tenure of leaders (Bienen and van de Walle 1991; Bueno de Mesquita et al. 2001). To provide some baseline, this article analyzes the new data to assess how a broad range of domestic and international factors affect the tenure of leaders.

To promote further theoretical and empirical research on the role of leaders, it is necessary to show that a focus on leaders has the potential to provide new insights on important questions. To that end, we examine whether the assumption that war is ex post inefficient

Giacomo Chiozza is a Ph.D. candidate, Department of Political Science, Duke University, 326 Perkins Library, P.O. Box 90204, Durham, NC 27708 (gc4@duke.edu). H. E. Goemans is Assistant professor, Department of Political Science, University of Rochester, Rochester, NY 14627 (hgoemans@mail.rochester.edu).

Earlier drafts of this article were presented at the PIPES seminar at the University of Chicago, the University of Virginia, and the Annual Convention of the American Political Science Association, Washington D.C. We thank the commentators at those presentations; in particular we thank Thomas Blackwell, Chris Gelpi, Jessica Hardesty, Bob Keohane, Craig Koerner, Jeff Legro, Thomas Lumley, Kevin Morrison, Davide Raggi, Dan Reiter, Sebastian Rosato, Angelo Secchi, Randolph Siverson, Alastair Smith, David Soskice, Allan Stam, and Terry Therneau. Mistakes, omissions, and other assorted infelicities are our own responsibility. Authors' names are in alphabetical order.

American Journal of Political Science, Vol. 48, No. 3, July 2004, Pp. 604-619 
still holds when we shift our focus from states-as-unitaryactors to the political leaders who make the decisions to engage their countries in conflict. We find that the societal costs of war generally do not translate into political costs for leaders. Specifically, we find that compared to crises the additional costs of war do not significantly reduce the tenure of leaders. Therefore, mechanisms other than private information and incentives to misrepresent, commitment problems and issue indivisibility-all based on the assumption that war is ex post inefficient for states as unitary rational actors-may provide rationalist explanations for war. Our analysis may provide some building blocks for the construction of such new rational explanations for war. In that regard, two sets of findings stand out. First, when we compare crises to peace, we find that only a defeat significantly affectse.g., reduces - the tenure of mixed regime and autocratic leaders. Victory or a draw in a crisis improve the tenure prospects of autocratic leaders, but neither increase nor reduce tenure for any other types of leaders. Moreover, no crisis outcome - not even defeat - significantly affects the tenure of democratic leaders. Second, when we compare wars to peace, we find the same pattern: victory in war does not significantly increase tenure for any type of leader; defeat in war only significantly reduces the tenure of mixed regime and autocratic leaders; a draw in war does not significantly affect the tenure of any leaders. Again, war, no matter the outcome, does not significantly affect the tenure of democratic leaders.

We proceed as follows. In the first section, we discuss the central assumption in the recent rationalist literature on war, the claim that war is ex post inefficient. In the second section, we describe our research design and our main variables. In the third section, we present the results of our analyses. We then briefly discuss how to calculate the substantive effects of time-varying variables in duration models. In the conclusion we summarize our findings and discuss the implications for the literatures on tenure and the use of force.

\section{The Costliness of War}

In an important article, Fearon (1995) sought to provide answers for what he called the fundamental puzzle of war: the occurrence of war in spite of its costliness. Central to his argument is the claim that "[a]s long as both sides suffer some costs for fighting, then war is always inefficient $e x$ post" for rational unitary-actors (383). War is inefficient ex post because the pie to be divided between the opponents will be smaller after the war than it was before the war. He proposed three mechanisms to explain why, when war is negative-sum, rational unitary-actors may be un- able to reach agreements that avoid war. Specifically: (1) private information and incentives to misrepresent one's capabilities, resolve, or anticipated costs of war, (2) commitment problems, and (3) issue indivisibilities.

Nevertheless, Fearon explicitly acknowledged that his focus on "rational unitary-actor explanations" addressed only one of three types of arguments that could explain the occurrence of costly wars. The first of these two alternative types of arguments claims that leaders are sometimes, or even always, irrational. Such arguments currently are poor candidates for systematic examination. The second alternative, however, is not. As Fearon noted, "war may be rational for... leaders if they will enjoy various benefits of war without suffering costs imposed on the population." It deserves emphasis to note that he continued "I believe that 'second-image' mechanisms of this sort are very important empirically. .." $(379$, fn. 1$)$. If leaders enjoy "various benefits of war" which more than offset their costs, then war is obviously no longer ex post inefficient for the opposing leaders, and Fearon's three mechanisms are no longer sufficient to explain war. Instead, new mechanisms could come to the fore, perhaps explaining why, when, and which leaders enjoy "various benefits of war" that more than offset its costs. Below, we briefly discuss the potential costs and benefits of war for leaders, as operationalized in terms of their time in office.

It is by no means obvious why the costs of war to the overall society should directly translate into political costs for the leader; after all, the costs of war are sunk. It would be irrational for citizens to base their decision for removal on such sunk costs since their decision can not affect these costs. The past can only be used as a rational basis for decision if it is prologue to the future. This simple argument suggests that the costs of war for societies as a whole do not directly and straightforwardly translate into political costs for their leaders. Instead, political processes will fundamentally mediate the costs and benefits of war into political costs and benefits for leaders. Therefore, political processes will determine whether war is negativesum for opposing leaders.

On the one hand, voters and members of the (s)electorate (Bueno de Mesquita et al. 2003) may punish their leaders for the costs of war in order to deter future leaders from risky and costly adventures, or simply because leaders failed to prove their mettle during the hardship of conflict (Downs and Rocke 1994; Hess and Orphanides 1995). On the other hand, war may actually provide opportunities to leaders not available during peace time. First, war opens the door for policies that would never be deemed acceptable in peacetime, and such policies can be used to buy off core constituencies or get rid of potential opponents. Leaders can use war to alter 
the institutional structure of the country or postpone elections. In general, war and international conflict can provide leaders unique opportunities to deal with their opposition. Opponents, be they actual or potential, can be sent to the front to fight and die for the country; and war can provide many opportunities to delegitimize or outmaneuver domestic adversaries. Tullock offers a particularly striking example:

When Mao Tse-Tung seized control of China, he actually was the head of an organization in which there were in essence 5 armies all of which had been built up by one leader from practically nothing and which were to a considerable extent loyal to that leader. Mao may have been able to deal with this by ordinary methods, but the Korean War gave him a wonderful opportunity. He in essence drafted from each of these armies specific units to send to the Korean War. These units were then rotated back to China on a regular basis, but were not returned to their original army. As a result at the end of the Korean War the 5 major armies had melded into one. Mao was then able to remove the four most important generals from their positions of personal power. $(1987,29)$

Second, leaders might gain time in office as a result of war because they engaged in a "gamble for resurrection" (Downs and Rocke 1994). Third, war can allow leaders to reveal their competence (Smith 1998).

For war to be ex post inefficient, the punishment mechanisms must strictly dominate the reward mechanisms not just for one side, but for the opponents combined. Fearon's rationalist explanations for war depend crucially on the assumption that the pie to be divided among the opponents will be smaller after war than if the crisis is resolved without war, e.g., war is negative-sum. For war to be negative-sum for leaders, the tenure-pie to be divided among the opposing leaders would also have to be strictly smaller after war than after a crisis that did not escalate to war. Only then can we rely on Fearon's three rationalist explanations for war, if we shift our focus from the state as a unitary rational actor to the leader. Hence our first hypothesis:

\section{H.1: War is Ex Post inefficient Hypothesis The} tenure of opposing leaders will be lower after a war than after a crisis.

For war to be negative-sum for opposing leaders (e.g., costly in Fearon's sense), the hazard of losing office of winners and losers in wars must be higher than the haz- ard of winners and losers in crises. War would not be negative-sum, for example, if leaders did not face a higher hazard after a draw-which by definition includes both sides-in a war than after a draw in a crisis. If war is not always negative-sum for leaders, the necessary condition for the exclusiveness of Fearon's three mechanisms no longer holds, and space is opened up for new, leader based, rationalist explanations for war.

Alternatively, it could be argued that war will prove not expost inefficient because of selection effects (Bueno de Mesquita et al. 1999; Schultz 2001). Leaders pursue time in office as their goal and take decisions to improve their political careers. Therefore, they wage those conflicts that are consistent with that goal, and avoid those that are not. Following Schultz's (2001) arguments about crisis behavior, it could be argued that the probability of observing tenure related punishments or rewards for leaders depends on the value of those punishments and rewards. The higher the tenure punishments from war, the less likely we should be to observe such a decrease in tenure as a result of war. Conversely, the higher the tenure rewards from war, the more likely we should be to observe such increased tenure as a result of war. Note that if leaders do indeed select their wars in this manner, both patterns should emerge empirically: leaders should not be punished for losing wars and should be rewarded handsomely for winning wars. Hence our second hypothesis:

H.2: Selection Effects Hypothesis Leaders do not face a higher hazard of removal as a result of defeat but do face a lower hazard as a result of victory.

If war is found not to have been expost inefficient for leaders historically, the selection effect hypothesis would offer a potential explanation. It would also suggest novel directions for the search for rational explanations for war, in particular about the mechanisms that leaders employ to select their wars. ${ }^{1}$

\section{Research Design}

To test our two hypotheses on war and the tenure of leaders, we estimate a series of hazard models in which the dependent variable measures how long a leader has

${ }^{1}$ It might appear that Hypotheses H.1 and H.2 call for a test on a dyadic data set with pairs of leaders as its unit of analysis and joint tenure as the dependent variable. Analysis of such a data set, however, would face extremely difficult conceptual hurdles. As we show below, a test of the combined effects of victory, defeat, and draw, for wars and crises respectively, offers a much simpler but powerful test of H.1 and H.2. This approach has the added benefit that we can offer a full set of results of the factors that affect the tenure of leaders. 
remained in office. We estimate semiparametric Cox proportional hazard models, the workhorse of duration analysis (Therneau and Grambsch 2000).

We innovate this specification in three ways. First, we add a frailty term, that is, an additional unmeasured covariate $\alpha_{i}$ that is sampled from a Gamma distribution with mean 1 and variance $\theta$ and that multiplicatively affects the baseline hazard. ${ }^{2}$ The frailty parameter is conceptually analogous to a random effect that assesses whether some leaders are more likely to leave power, all the other measured factors being equal. Those leaders for whom $\alpha_{i}$ is greater than 1 are more prone to removal from office than our explanatory variables account for. Leaders for whom $\alpha_{i}$ is smaller than 1 are less likely to lose power, all else being equal. Two components in the model, therefore, account for the variation in the risk of losing office among leaders, the explanatory variables and the frailty, with the frailty term incorporating the unmeasured heterogeneity across units. In our specification, we cluster observations-i.e., leaders-by countries. In other words, the frailty term is assumed to be constant within country groups. We cluster on countries because leaders ruling the same country are likely to have chances of survival that are dependent in some general way on country specific factors that go beyond the explanatory variables in the model (Therneau and Grambsch 2000, 231-60).

The second innovation regards the extension of the Cox hazard model to account for nonproportional hazards (Box-Steffensmeier, Reiter, and Zorn 2003). The Cox hazard model is built on the key assumption of proportional hazards: regardless of when it occurs in the life history of a subject, a change in an explanatory variable has an effect on the hazard that is proportional and constant over time. This is a powerful assumption that might serve researchers well in a large range of instances, but it is an assumption that should not be taken for granted. Explanatory variables might have effects that either wax or wane as time goes by, thus altering the conditions under which a process or an event terminates. This is particularly true in politics: time is a fundamental political process that shapes the context in which political actors interact. We might expect that over time political leaders might become more skilled at wielding power by the mere exercise of power, and thus become able to steer through politically troubled waters that would have led to their removal in the early phases of their tenure. This conjecture implies that variables measuring "politically troubled waters" should be associated with large and positive

${ }^{2}$ The specification for the hazard takes the following form: $h_{i}(t \mid \mathbf{x})=h_{0 i}(t) \alpha_{i} \exp \left(\sum_{j=1}^{p} \beta_{j} x_{j}\right)$, where $h_{0 i}(t)$ is the baseline hazard, and $\alpha_{i}$ follows a Gamma distribution with shape and scale parameters equal to $1 / \theta$. coefficients for newly appointed leaders, but smaller or approximately zero coefficients for long-serving political leaders. $^{3}$

Failing to detect, and control for, time-varying effects, then, not only mischaracterizes the political dynamics that underlie leadership tenure, but also leads to biased and inefficient estimates. Therefore, we run the relevant specification checks based on the analysis of the scaled Schoenfeld residuals for all the models we estimate. We then reestimate the models including an interaction effect between each variable that fails to meet the proportional-hazard assumption and the logarithm of time. The coefficients associated with each timeinteraction variable measure how a covariate effect would increase or decrease as a function of time in office.

As often the case with political science data, our data set is affected by the presence of missing values on some of the variables, which leads to the loss of valuable information and potentially biases estimates and inferences (King et al. 2001). ${ }^{4}$ Missing data can be particularly pernicious when estimating hazard models if data on some variables are less likely to be recorded when an event terminates. Therefore, the third methodological innovation in our research design is the use of multiple imputation to fill in the missing values. Following Schafer's (1997) approach, we use data augmentation under a multivariate normal model based on all the explanatory variables and the time-in-office dependent variables (including the dichotomous indicator for office removal). We run five parallel chains of 500 steps each, and we set the starting values for each chain by using the EM estimates of the model parameters computed on a bootstrap sample a quarter of the size of the whole dataset (Allison 2002, 38, fn. 11). ${ }^{5}$ This way, we create five imputed data sets with no missing records. We estimate our models on each data set, we report the mean of the five estimates for each models' coefficients, and we compute the standard errors and significance levels using Rubin's formulas (Rubin 1987, $76-79) .^{6}$

${ }^{3}$ This conjecture is consistent with the results on leaders' survival
in office obtained by Bienen and van de Walle (1991) and Bueno
de Mesquita and Siverson (1995).

${ }^{4}$ We have complete records for 9194 (91.60\%) observations comprising 1900 leaders $(92.73 \%)$. Missing values are found in seven variables.

${ }^{5}$ The EM algorithm converges in a number of iterations ranging from 15 to 33 .

${ }^{6}$ The standard errors are computed as the square root of the average of the within-samples variances plus the variance of the coefficient estimates across samples (multiplied by the correction factor, $1+1 / M$, where $M$ is the number of imputed data sets). The parameter estimates from a multiple imputation procedure follow a $t$-distribution with the degrees of freedom equal to 
The data set we analyze expands and updates Chiozza and Goemans' (2003) compilation of leaders: we identify all the leaders holding executive power from 1919 through 1999 and we record the date on which each leader entered into power and the date on which he was removed from office. Leaders still in power as of the 31st December 1999, when we stop collecting data, are coded as censored observations. Likewise, we code as censored observations the leaders who died a natural death and secondterm American Presidents after Franklin Roosevelt. ${ }^{7}$ We exclude from the sample the leaders that were governing countries not yet formally independent, and we start measuring time in office from the day of state independence. ${ }^{8}$ Our data set comprises 2049 leaders from 166 countries. Each leader's spell in office is split into yearly observations: this division is chosen because most of our explanatory variables are measured annually. This way, each leader has one record each calendar year he was in power. This creates a data set with 10037 observations.

In our data set, the median duration in office is 1190 days (about three years and three months). If we distinguish leaders by domestic political institutions, large differences emerge: the median duration in office is about seven years for Autocrats; about two years and eight months for Mixed regime leaders; about two years and five months for leaders of Presidential democracies; and about one year and 11 months for leaders of Parliamentary democracies. The longest serving leader is King Hussein of Jordan, who was in power for 46 years and six months, from the 11th of August 1952 to the 7th of February 1999.

While the explanatory variables are detailed in Appendix A, we briefly discuss here how we code conflict involvement and outcomes. We measure conflict using two batteries of indicators that distinguish international crises short of war and wars. Our primary source for the conflict data is Gelpi and Griesdorf's (2001) list of conflict events from the International Crisis Behavior (ICB) Project of Brecher and Wilkenfeld (1997) for the years

$(M-1)\left(1+r^{-1}\right)^{2}$, where $r$ is the ratio of the between-to-within variances (multiplied by the correction factor $(1+1 / M)$ ). For the nuisance parameters, such as the variance of the random effect $\theta$, whose significance levels are based upon $\chi^{2}$ tests, we compute the repeated-imputation p-values using the approach of Li et al. (1991). For the tests of joint significance and the tests of linear hypotheses, we use the multivariate extension of the approach presented above as is described in Rubin and Schenker (1991).

${ }^{7}$ Bienen and van de Walle $(1991,43)$ and Bueno de Mesquita et al. $(2001,191)$ use a similar coding rule for the leaders who died of natural causes while still in power.

${ }^{8}$ The dates of state independence are taken from the Polity IV (2000) data set and the State System Membership List from the Correlates of War Project (2003). Whenever the two data sources disagreed, we chose the most recent of the two dates. from 1919 to 1994 . We added the conflict events from the latest version of the ICB data (2003) for the years from 1995 to 1999. We use the ICB four-point indicator for the severity of conflict to distinguish wars and crises: confrontations in which serious clashes, minor clashes, or no violence occurred are coded as crises, while full-scale wars are accordingly coded as wars. Conflict involvement is measured by four dummy indicators, two for each type of conflict, that distinguish whether a leader participated in a conflict as a challenger or as a target. Thus, peace is the excluded category.

Conflict outcomes are identified by three indicators that measure whether a given international confrontation ended in victory, defeat, or draw in line with Gelpi and Griesdorf's (2001) and the ICB's (2003) codings. The outcome of the conflict is measured in the last year it was waged and in the subsequent years until there is a leadership change. We use a hyperbolic transformation to discount the effects of conflict outcomes over time. Each of the three outcome variables is coded using the following time-dependent function: Outcome $e_{t}=1 / t$, where $t$ represents the number of years since the termination of the conflict. Thus, in the year the outcome is realized the outcome indicator - be that victory, defeat, or draw-is coded as 1 , in the second year after the end of the conflict it is coded as .5 , in the third year as .333 , and so on. The conflict indicators are coded as 0 for the leaders who have not fought a conflict or who were removed before the conflict ended. This coding choice reflects our intuition that the effects of the outcomes of international conflict can well linger for a long time among voters or members of the ruling coalition, but that over time the importance of the outcomes of conflict will dissipate.

\section{Data Analysis}

We estimate two main models: Model 1 assesses the overall effects of crises and wars on leaders' tenure while Model 2 distinguishes the effects of conflict outcomes across domestic regime types. We split the presentation of the results of both models in two tables. Table 1 reports the findings on the whole set of nonconflict related variables: domestic institutions, civil war, economic development, trade openness, population size, leaders' age, and previous spells in office; Table 2 presents the findings on the conflict variables. We report the model-related summary statistics at the bottom of Table 1. The coefficients measure the impact of the explanatory variables on the hazard of losing office; thus, positive coefficients imply that as an independent variable increases the risk of removal from office increases (and expected time in office decreases). 
TABLE 1 Frailty Cox Hazard Models of the Determinants of Leaders' Office Removal (Part 1) ${ }^{a}$

\begin{tabular}{|c|c|c|c|c|c|c|}
\hline \multirow[b]{2}{*}{ Variables } & \multicolumn{3}{|c|}{ Model 1} & \multicolumn{3}{|c|}{ Model 2} \\
\hline & $\mathbf{b}$ & Std. Err. & p-value & $\mathbf{b}$ & Std. Err. & p-value \\
\hline Mixed regime & 4.104 & 0.494 & $<0.001$ & 4.221 & 0.499 & $<0.001$ \\
\hline Mixed regime $\times \ln (t)$ & -0.468 & 0.068 & $<0.001$ & -0.485 & 0.069 & $<0.001$ \\
\hline Parliamentary democracy & 2.785 & 0.544 & $<0.001$ & 2.940 & 0.549 & $<0.001$ \\
\hline Parliamentary democracy $\times \ln (t)$ & -0.179 & 0.078 & 0.021 & -0.202 & 0.079 & 0.011 \\
\hline Presidential democracy & 3.072 & 0.649 & $<0.001$ & 3.260 & 0.659 & $<0.001$ \\
\hline Presidential democracy $\times \ln (t)$ & -0.300 & 0.094 & 0.001 & -0.327 & 0.096 & 0.001 \\
\hline Civil war & 0.460 & 0.399 & 0.248 & 0.417 & 0.400 & 0.297 \\
\hline Civil war $\times \ln (t)$ & 0.045 & 0.063 & 0.468 & 0.053 & 0.063 & 0.396 \\
\hline Economic development & -0.832 & 0.078 & $<0.001$ & -0.833 & 0.078 & $<0.001$ \\
\hline Economic development $\times \ln (t)$ & 0.111 & 0.011 & $<0.001$ & 0.110 & 0.012 & $<0.001$ \\
\hline Change in economic development & -0.004 & 0.001 & 0.006 & -0.004 & 0.001 & 0.005 \\
\hline Trade openness & -0.046 & 0.023 & 0.047 & -0.050 & 0.023 & 0.032 \\
\hline Change in trade openness & -0.001 & 0.001 & 0.084 & -0.001 & 0.001 & 0.076 \\
\hline Population & 2.429 & 0.097 & $<0.001$ & 2.420 & 0.098 & $<0.001$ \\
\hline Population $\times \ln (t)$ & -0.370 & 0.014 & $<0.001$ & -0.368 & 0.014 & $<0.001$ \\
\hline Age & 0.155 & 0.011 & $<0.001$ & 0.156 & 0.011 & $<0.001$ \\
\hline Age $\times \ln (t)$ & -0.022 & 0.002 & $<0.001$ & -0.022 & 0.002 & $<0.001$ \\
\hline Previous times in office & -0.229 & 0.048 & $<0.001$ & -0.228 & 0.048 & $<0.001$ \\
\hline No. of obs. & 10,037 & & & 10,037 & & \\
\hline No. of subjects & 2,049 & & & 2,049 & & \\
\hline No. of failures & 1,828 & & & 1,828 & & \\
\hline Log-likelihood & -10183.990 & & & -10170.773 & & \\
\hline Wald-test & $D=62.277$ & $\mathrm{p}<0.001$ & & $D=38.796$ & $\mathrm{p}<0.001$ & \\
\hline$\theta$ & 0.763 & $\stackrel{\tilde{D}}{\tilde{D}}=7.543$ & $\mathrm{p}<0.001$ & 0.761 & $\tilde{D}=7.463$ & $\mathrm{p}<0.001$ \\
\hline
\end{tabular}

${ }^{a}$ Missing values are imputed using MI, $M=5$, (Rubin 1987; Schafer 1997). Estimates and standard errors are adjusted using Rubin's (1987, 76-77) formulas. The Wald test refers to a test of the hypothesis that all coefficients are simultaneously equal to 0 . For the $D$ statistic in the Wald test, see Rubin and Schenker $(1991,590)$. For the $\tilde{D}$ statistic for the significance of $\theta$, see Li et al. (1991). The frailty parameter $\theta$ measures the variance of a Gamma distribution with mean equal to 1.

The significance of each variable is measured by two-tailed tests.

Before analyzing the effect of the explanatory variables on the hazard of office removal, we discuss the inclusion of the time-interaction variables to control for nonproportional effects, and the presence of unobserved heterogeneity at the country-level as measured by the variance of the frailty term. ${ }^{9}$

First, in both models, the global test for nonproportionality yielded large and highly significant $(\mathrm{p}<.001)$ test statistics, clearly indicating a violation of the assumption of proportional effects. In the variable-specific tests,

\footnotetext{
${ }^{9}$ Regarding the third innovation in our research design, the point estimates we obtain with list-wise deletion yield coefficients mostly similar to those obtained with multiple imputation. The estimated relative increase in variance due to the presence of missing values is at its highest at $7.3 \%$ for the coefficient on the change in tradeopenness variable.
}

eight variables appear to be responsible for this violation: the correlation between the scaled Schoenfeld residuals for Mixed regime, Parliamentary democracy, Presidential democracy, Civil war, Economic development, Population, Age, and War involvement as a challenger, on the one hand, and the logarithm of time, on the other, was statistically significant at the .05 level. For these variables, we included a time-interaction term. ${ }^{10}$

\footnotetext{
${ }^{10}$ The models with no time interactions, upon which the nonproportional hazard tests were conducted, and the tests themselves are available upon request. We computed the significance levels for the $\chi^{2}$ statistics in the nonproportional hazard tests using the approach of Li et al. (1991) to account for the use of multiple imputation. In Model 2, the scaled Schoenfeld residuals of an additional variable, the interaction between Parliamentary democracy and Draw in war, are apparently correlated with time. However, an inspection of the plot of the residuals indicates that this correlation is induced by the presence of three data points with large residuals, and not by any systematic temporal pattern. The inclusion of the time interaction
} 
TABLE 2 Frailty Cox Hazard Models of the Determinants of Leaders' Office Removal (Part 2)

\begin{tabular}{|c|c|c|c|c|c|c|}
\hline \multirow[b]{2}{*}{ Variables } & \multicolumn{3}{|c|}{ Model 1} & \multicolumn{3}{|c|}{ Model 2} \\
\hline & $\mathbf{b}$ & Std. Err. & p-value & $\mathbf{b}$ & Std. Err. & p-value \\
\hline Crisis involvement as chall. & -0.893 & 0.234 & $<0.001$ & -0.972 & 0.241 & $<0.001$ \\
\hline Crisis involvement as target & -0.225 & 0.168 & 0.179 & -0.282 & 0.174 & 0.104 \\
\hline War involvement as chall. & -2.038 & 1.503 & 0.175 & -1.070 & 1.500 & 0.475 \\
\hline War involvement as chall. $\times \ln (t)$ & 0.226 & 0.222 & 0.309 & 0.043 & 0.228 & 0.852 \\
\hline War involvement as target & -0.123 & 0.202 & 0.541 & -0.084 & 0.209 & 0.689 \\
\hline Win crisis & -0.061 & 0.236 & 0.796 & & & \\
\hline Lose crisis & 0.686 & 0.212 & 0.001 & & & \\
\hline Draw crisis & -0.194 & 0.222 & 0.381 & & & \\
\hline Win war & -0.274 & 0.485 & 0.572 & & & \\
\hline Lose war & 1.082 & 0.263 & $<0.001$ & & & \\
\hline Draw war & -0.327 & 0.429 & 0.445 & & & \\
\hline Autocracy $\times$ Win crisis & & & & -1.308 & 0.747 & 0.080 \\
\hline Autocracy $\times$ Lose crisis & & & & 1.357 & 0.362 & $<0.001$ \\
\hline Autocracy $\times$ Draw crisis & & & & -1.181 & 0.584 & 0.043 \\
\hline Mixed reg. $\times$ Win crisis & & & & -0.016 & 0.414 & 0.969 \\
\hline Mixed reg. $\times$ Lose crisis & & & & 0.770 & 0.316 & 0.015 \\
\hline Mixed reg. $\times$ Draw crisis & & & & -0.217 & 0.341 & 0.525 \\
\hline Parl. democ. $\times$ Win crisis & & & & 0.302 & 0.349 & 0.388 \\
\hline Parl. democ. $\times$ Lose crisis & & & & 0.304 & 0.403 & 0.450 \\
\hline Parl. democ. $\times$ Draw crisis & & & & 0.238 & 0.356 & 0.504 \\
\hline Pres. democ. $\times$ Win crisis & & & & 0.265 & 0.464 & 0.568 \\
\hline Pres. democ. $\times$ Lose crisis & & & & 0.269 & 0.635 & 0.672 \\
\hline Pres. democ. $\times$ Draw crisis & & & & 0.072 & 0.504 & 0.887 \\
\hline Autocracy $\times$ Win war & & & & -0.521 & 0.953 & 0.585 \\
\hline Autocracy $\times$ Lose war & & & & 2.532 & 0.505 & $<0.001$ \\
\hline Autocracy $\times$ Draw war & & & & -1.303 & 1.346 & 0.333 \\
\hline Mixed reg. $\times$ Win war & & & & -1.520 & 2.317 & 0.512 \\
\hline Mixed reg. $\times$ Lose war & & & & 1.054 & 0.414 & 0.011 \\
\hline Mixed reg. $\times$ Draw war & & & & -0.552 & 0.642 & 0.390 \\
\hline Parl. democ. $\times$ Win war & & & & -0.163 & 0.623 & 0.794 \\
\hline Parl. democ. $\times$ Lose war & & & & 0.482 & 0.461 & 0.296 \\
\hline Parl. democ. $\times$ Draw war & & & & 0.384 & 0.647 & 0.553 \\
\hline Pres. democ. $\times$ Win war & & & & -0.339 & 1.686 & 0.841 \\
\hline Pres. democ. $\times$ Lose war & & & & 0.778 & 0.844 & 0.357 \\
\hline Pres. democ. $\times$ Draw war & & & & -0.211 & 1.589 & 0.895 \\
\hline
\end{tabular}

${ }^{a}$ Model related summary statistics are reported in Table 1.

Second, we find that the inclusion of the frailty parameter substantially improves the fit of the models: the statistical tests on the variance parameter $\theta$ are highly

variables affected the size and significant of other coefficients beyond those associated with the nonproportional variables: in particular, in the models with no time-interactions the coefficients on Victory in crisis and on Draw in crisis are both negative and significant at the .02 level; the coefficient on Victory in war is negative and significant at the .1 level. significant in both models, as indicated by the $\tilde{D}$ statistics (Li et al. 1991). The probability that a frailty term $\alpha_{i}$ is smaller than 1, which indicates units less prone to failure than portrayed in the explanatory variables, is about 616 . Overall, the $95 \%$ confidence interval for the frailty terms spans from .05 and 3.29. To give some intuition of the substantive relationships behind the frailty terms, the country with the largest estimated frailty is Switzerland: the baseline risk of losing office for Swiss political leaders is about 
7.7 times larger than that of any other leaders, all else being equal. This finding is hardly surprising if we recall that Swiss leaders can only serve as the chair of the Federal Government for a constitutionally mandated term of one year. Twelve other countries have a frailty term greater than 2, including Estonia, Latvia, Ecuador, Syria, Bolivia, Greece, and Argentina. China, in contrast, has the lowest estimated frailty term: the chances of losing office of a Chinese leader are about $98.2 \%$ smaller than those of any other leaders, all else being equal. Chinese leaders, in other words, have been able to steer through political conditions that would have led to a leadership change in most other countries. Countries with very low frailty terms are the oil-producing Gulf countries Bahrain, Oman, Qatar, United Arab Emirates, and Saudi Arabia. It is not necessarily the case, though, that only Autocratic countries provide their leaders with political environments that are safer than what we are able to measure. India, for example, also has a baseline hazard that is about $97.6 \%$ smaller, all else being equal.

Turning our attention to the explanatory variables, the first thing to notice in Table 1 is that the effect of the variables measuring the domestic political and economic conditions of a country and the effect of the variables measuring the leaders' personal characteristics remain substantially identical across the two models. Leaders of Mixed regimes, leaders of Parliamentary democracy, and leaders of Presidential democracies face significantly higher risks of losing office than leaders who rule over Autocratic regimes: all dummy variables for the different domestic institutional arrangements are positive and significant. But it is also interesting to notice that the timeinteraction terms are negative and significant. Substantively, the higher hazards of losing office faced by all the non-Autocratic leaders tend to dissipate over time. The rate of "dissipation" is particularly pronounced for leaders of Mixed regimes. Indeed, in the very early phases of their tenure, leaders of Mixed regimes are more susceptible to removal than the leaders of more institutionalized democratic countries: of the three coefficients on the Regime type variables, theirs $\left(b_{\text {Mixed regime }}=4.104\right)$ is the largest. But just after about 15 months in office, the effect of Mixed regime institutions on leaders' survival is as large as that of democratic institutions. Moreover, the magnitude of the Mixed regime variable reaches the value of 0 after about 17 years, and ceases to be statistically different from 0 after about 10 years. ${ }^{11}$ Thus, all else being equal, leaders of Mixed regimes that manage to survive about a decade are as likely to lose office as leaders

\footnotetext{
${ }^{11}$ Friedrich (1982) and Gill (2001) offer a clear overview of the interpretation of the interaction terms in regression models.
}

of Autocratic regimes who also have survived about a decade.

For leaders of Parliamentary and Presidential democracies, on the other hand, the time to zero effect occurs well beyond the realm of what is politically (or biologically) feasible. If we exclude the brief period of time during which Mixed regime leaders face the highest risks of removal, Democratic leaders are systematically more likely to lose office than any other types of leaders. The coefficients on the Parliamentary democracy and Presidential democracy dummy variables are both positive and significant, but not statistically different from each other $(D=0.238, \mathrm{p}=.627) .{ }^{12}$ The less negative time-interaction effect on the Parliamentary democracy variable, however, indicates that over time the rate of leadership turnover is greater in Parliamentary democracies than it is in Presidential democracies. Our findings, then, suggest that there may be a higher degree of political instability in Parliamentary democracies. However, if we read this finding in light of the fact that Parliamentary democracies are less prone to authoritarian breakdowns than Presidential democracies, then, as Linz (1994) has famously argued, it would seem that the institutional arrangements found in a democratic parliamentary regime would make it easier to replace bad governments, and bad leaders, through constitutional means.

Related to the political situation in a country, we find that Civil war and its associated time-interaction effect, our indicator for domestic unrest, is positively associated with leadership change. Both coefficients are by themselves statistically undistinguishable from zero. Their linear combination $\left(b_{\text {Civil war }}+b_{\text {Civil war } \times \ln (t)}\right)$, however, rapidly becomes highly significant: after six months in office, a leader involved in a civil war is more likely to be removed from power. Despite the fact that the Civil wartime interaction term variable is not significant, therefore, there is some tentative evidence that civil wars tend to dislodge leaders that have remained in power a long time.

We next turn to the economic variables. The coefficients on the four variables measuring economic conditions show that in general the dynamics of the economy do affect leaders' tenure. The coefficient on the variable measuring the levels of Economic development is negative and significant, but it is associated with a positive and significant time-interaction. For short periods of time, early on in their careers, leaders of economically developed countries enjoy more secure tenure than leaders of less developed countries. However, this effect dissipates

\footnotetext{
${ }^{12} \mathrm{D}$ represents the generalization for multiply-imputed data sets of a Wald test for the null hypothesis that two coefficients are equal, against the alternative hypothesis that they are different (Rubin and Schenker 1991).
} 
rather quickly: it reaches 0 after about five years, and it is statistically undistinguishable from 0 after about three years. Economic development starts exerting a positive and significant effect on the hazard of removal for leaders that have remained in power at least nine years. As would be expected, but contrary to earlier findings by (Cheibub and Przeworksi 1999), the variable measuring the yearly change in Economic development is negative and highly significant. Thus, leaders ruling over countries that experience growth in economic activity on average enjoy longer time in office.

As indicated by the coefficients on the variable measuring trade levels, countries open to international trade grant their rulers a longer time in office. On the other hand, the variable measuring the change in trade levels only has a marginally significant impact on tenure. Openness to trade seems to be rewarded in terms of reduced hazards of office removal for leaders, despite the associated greater levels of external risks that come with trade. This finding seems to speak to the connection between trade and domestic institutional responses that several authors have identified. In particular, countries with open economies have bigger, more interventionist, governments. Rodrik (1998) has shown that this larger governmental role provides social insurance in economies exposed to external economic shocks. Our findings seem to indicate that such political strategies are also consistent with leaders' desire to remain in power.

Contrary to the results reported by Bienen and van de Walle $(1991,66)$ we find that population size is significantly associated with patterns of leadership removal. In the early phases of their spells in power, leaders of large countries face higher chances of losing office than leaders of smaller countries. But this effect is reversed as time goes by. The turning point occurs after about two years. From about two-and-a-half years in office onwards the effect of population size is negative and significant, thus making leaders of populous countries less likely to lose power.

Finally, the two variables measuring some personal attributes of leaders - their age and their previous experience as leaders-are systematically associated with office survival. The effects of leaders' Age are particularly interesting. We find that biological time is not necessarily a liability for political leaders. The coefficient on Age is positive and significant, but its associated interaction term is negative and significant, thus indicating a diminishing effect over time until the effect changes sign. Our results indicate that after only three years in power leaders are no longer negatively affected by their older age. In other words, the experience that they gain by staying in power makes them more effective at wielding power and, therefore, less prone to office removal. This result is corrobo- rated by the finding on the variable measuring the number of spells in office: the negative and significant sign implies that "come-back" politicians are able to establish a firmer grasp on office.

\section{The Effects of International Conflict on Leaders' Tenure}

In this section we concentrate on the effects of conflict and its outcomes on the tenure of leaders. We first examine the results of Model 1, which assesses the impact of conflict involvement and conflict outcomes for crises and wars for all leaders. Next, we move to the results of Model 2 , which analyzes the impact of conflict outcomes across domestic political regimes. The key finding in Table 2 is that the tenure consequences of wars are not systematically worse than the tenure consequences of crises. Thus, compared to crises, the additional costs of war do not systematically and significantly affect the tenure of leaders. Contrary to hypothesis H.1, war therefore does not appear to be negative-sum for opposing leaders. Nevertheless, for individual leaders war can be quite costly. Defeat-both in crises and wars-significantly reduces the tenure of leaders.

First, we observe that the findings on the leader's role in the conflict remain similar in Model 1 and Model 2. With one exception, a leader's role in conflict does not seem to affect his hazard of losing office. The exception is leaders who participate in crises as challengers; they seem to face a lower hazard of removal from office. The significant coefficient on crisis involvement as a challenger is in line with previous results that initiators in war are rewarded with longer tenure (Bueno de Mesquita et al. 2001). However, this finding has to be interpreted with care. On the one hand, it might be that initiation of a crisis short of war increases the leader's prospects of remaining in office because he outmaneuvered domestic opponents, "gambled for resurrection" (Downs and Rocke 1994), or revealed his competence. On the other hand, the causality might run the other way; that is, it could be that only secure leaders (who face a low hazard of losing office) initiate crises (Gaubatz 1991; Chiozza and Goemans 2003).

We next shift from conflict roles to conflict outcomes. Model 1 suggests that victories and draws in either type of international conflict do not significantly affect the careers of leaders. Leaders victorious in war or a crisis, and leaders who reach a draw, are as likely to remain in power as are leaders who remained at peace. Leaders defeated in war or a crisis, in contrast, are much less likely to stay in power. Individual leaders thus clearly face significant political costs when they are defeated in an international 
conflict. It is important to note, however, that these results do no allow us to infer that war is negative-sum.

First, when we compare the hazard of defeat in a crisis and of defeat in war, we find that defeat in war produces a larger coefficient than defeat in a crisis, but these two coefficients are not statistically different from each other $(D=1.024, \mathrm{p}=.316)$. Victory decreases the hazard of losing office, but the difference between victory in wars and victory in crises is not statistically significant $(D=$ $.113, \mathrm{p}=.738$ ). Seemingly in favor of the war-is-ex-postinefficient argument, the rewards of victory do not offset the punishments of defeat: both for crises and wars, the absolute magnitude of the coefficient on Victory is smaller than that of the coefficient on Defeat. A test of $H_{0}: b_{\text {Win crisis }}$ $+b_{\text {Lose crisis }}=0$ and a test of $H_{0}: b_{\text {Win war }}+b_{\text {Lose war }}=0$ against the alternative hypothesis that the sum of the two coefficients is different from 0 , however, yield insignificant $D$ statistics $(D=2.419, \mathrm{p}=.125$ for crises; $D=$ $1.405, \mathrm{p}=.241$ for wars). Moreover, the combined tenure of victorious and defeated leaders is not lower after war than after a crisis: in other words, the tenure "contraction" that the victorious and the defeated leader jointly experience is not larger after wars than it is after crises. ${ }^{13}$ Remarkably, draws, the most likely outcome of international crises (Gelpi and Griesdorf 2001), leave leaders' tenure unscathed. The finding that draws in war do not reduce tenure as compared to peace, and that they do not hurt leaders' tenure more than draws in crises $(D=0.056$, $\mathrm{p}=.814)$ is sufficient to conclude that war is not negativesum for office-seeking leaders. Hypothesis H.1 must thus be rejected. At a very minimum, this suggests that rational explanations for war other than private information, commitment problems, and issue indivisibility deserve scholarly attention. A focus on leaders and their incentives may reveal new mechanisms for war. Leaders with high levels of risk aversion or leaders with little confidence in their abilities to prevail or at least reach a draw might find that the lottery of war is indeed not worth the higher risk of losing office. Otherwise, our findings indicate that wars create political dynamics not entirely captured by the logic of asymmetric information and credible commitments (Fearon 1995).

Our second hypothesis-the Selection-Effects hypothesis-also does not appear to survive careful empirical scrutiny. Our results indicate that leaders face gloomier tenure prospects if defeated but no rosier prospects if victorious. This finding would seem to be a prima facie indication that leaders are not very successful

${ }^{13}$ The test of $H_{0}: b_{\text {Win crisis }}+b_{\text {Lose crisis }}=b_{\text {Win war }}+b_{\text {Lose war }}$, against the alternative hypothesis that the sum of the Victory and Defeat coefficients after crises and wars is different, yields $D=0.053, \mathrm{p}=$ .819 . at selecting their international conflicts. The major thrust of the selection-effects argument, however, is to suggest that both incentives and ability to strategically select wars depend on domestic political institutions; indeed, it has been argued that the ability to select is the exclusive preserve of democratic regimes (Schultz 2001; Reiter and Stam 2002).

In Model 2, therefore, we expand our empirical inquiry to examine how regime type mediates the outcomes of international conflict. We therefore examine how the interaction between regime type-autocracy, mixed regime, parliamentary, and presidential democracyand the outcome of international conflict-win, lose, or draw-affects the hazard of losing office. ${ }^{14}$ Our results clearly indicate that domestic political institutions significantly moderate how the outcome of international conflict affects the tenure of leaders.

First, for Autocrats the hazard of losing office is very sensitive to the outcome of a crisis. If they win or draw, they are rewarded with a lower hazard; if they lose they face a higher hazard. Only defeat in a crisis affects the hazard of losing office for leaders of Mixed regimes. Surprisingly, for Democratic leaders neither victory, nor defeat, nor a draw in a crisis affects the hazard of losing office. Second, the fate of leaders seems less sensitive to the outcome of war than to the outcome of a crisis. The only outcome of war which affects the hazard of losing office is defeat, and defeat only lowers the hazard of Autocrats and leaders of Mixed regimes. Notably, defeat in war is substantially more costly for Autocratic leaders than it is for leaders of Mixed regimes: the coefficient on defeat in war is more than twice as large for Autocrats as it is for leaders of Mixed regimes, a statistically significant difference ( $D=4.320$, $\mathrm{p}=.043$ ). Again, neither victory, nor defeat, nor a draw in war affects the hazard of losing office for democratic leaders.

The finding that autocratic leaders benefit from victory or a draw in a crisis but not in a war, and suffer from defeat both in a crisis and in war, would suggest that autocratic leaders are always worse off after a war than after a crisis. Autocrats, however, do not face a systematically higher hazard of losing office as a result of war than as a result of a crisis. That is, a test of the null hypothesis $H_{0}: b_{\text {Aut } . \times \text { Wincrisis }}+b_{\text {Aut } . \times \text { Lose crisis }}+b_{\text {Aut. } \times \text { Draw crisis }}=$ $b_{\text {Aut. } \times \text { Win war }}+b_{\text {Aut. } \times \text { Lose war }}+b_{\text {Aut. } \times \text { Draw war }}$ suggests that

\footnotetext{
${ }^{14}$ For ease of interpretation, we include the interaction terms between autocracy and outcomes. This allows for a direct assessment of the impact of conflict outcomes for each regime type. Moreover, this obviates the need to compute the linear combination of the baseline coefficients and the interaction terms as shown in Friedrich (1982) and Gill (2001). Bueno de Mesquita et al. (2001) rely on a similar specification.
} 
the sum of the two sets of coefficients is not significantly different $(D=0.610, \mathrm{p}=.438)$. Moreover, the difference between victory in a war as compared to a crisis for Autocrats is not statistically significant $(D=0.313, \mathrm{p}=$ $.578)$, nor is the difference for a draw $(D=0.005, \mathrm{p}=$ $.944)$ or defeat $(D=2.555, \mathrm{p}=.116)$. Our data thus tantalizingly suggests that war between Autocrats might be negative-sum, but the result does not reach statistical significance.

We found that the outcome of crises and wars does not significantly affect the hazard of losing office for democratic leaders. The finding that only democratic leaders never suffer a higher hazard after defeat would seem to lend support for the modified selection effect hypothesis H.2 (Bueno de Mesquita et al. 1999; Reiter and Stam 2002). However, the selection effects logic is not entirely vindicated: democratic leaders do not gain at home from victory abroad. While democratic leaders may know how to select their fights and how to bring them to a successful conclusion, they apparently do not have the opportunity to pursue tenure enhancing conflicts. We note that there are no significant differences between parliamentary and presidential democracies when it comes to how the outcome of international conflict affects the tenure of their leaders. For the democratic peace theorists, this finding would support the conjecture that the strong aversion to the societal costs of war is embedded in all democratic systems.

\section{Estimation of Substantive Effects}

We have shown so far what variables are systematically associated with leaders' time in office, and the direction of their effects. What remains to be seen is their substantive impact and their relative importance. To this end, we use the survival function to measure how likely a leader is to survive over time under various configurations of the explanatory variables. Given the characteristics of our data, we are interested in leaders' expected survival probabilities given an entire path of explanatory variables, that is, a path of variables that might take on different values at different points in time (Therneau and Grambsch 2000, 268-72). When the explanatory variables change at fixed time intervals - every year in our data - the survival function can be written in the following way (Petersen 1986, 1991): $\operatorname{Pr}\left(T \geq t_{k} \mid X\left(t_{k}\right)\right)=\exp \left(-\sum_{j=1}^{k} \int_{t_{j-1}}^{t_{j}} h_{j}(u) d u\right)$, where $h_{j}$ is the hazard function associated with the covariates in each time interval and $t_{0}=0$. Thus, with timevarying covariates the survival function reduces to the product of the conditional survival functions for each of the time intervals from time $T=0$ to $T=t_{k}$. This formula yields estimates which measure the probability a leader will survive longer than time $T=t_{k}$ beginning from time $T=0$ and given the entire covariate history until $T=t_{k}$. This expression allows us to estimate survival probabilities for a hypothetical leader that governs through economic, political, and military conditions that vary over time.

To make this estimation, we identify counterfactual scenarios that are consistent with the time-varying characteristics of the variables included in our model. Basically, we distinguish a baseline scenario in which a leader rules in periods of peace where the economy-as measured by Economic development and Trade openness-expands at the median rate of growth observed in our sample. Against this backdrop, we assess how good and bad economic performance in a limited number of years affects tenure. By good economic performance, we mean that the levels of Economic development and Trade openness grow at annual rate equal to that of the 75th percentile, about $8.4 \%$ and about $14.9 \%$, respectively, in the first four years in office. The bad economic performance scenario, on the other hand, is created by setting the annual rate of change in economic development and trade-openness at the 25 th percentile, about $-3.1 \%$ and $-9.6 \%$, respectively, again in the first four years in office. We then add the impact of the international political variables. We set the frailty term at its mean value of 1 . The computations are based on the estimates of Model 2.

The first thing to notice in Table 3 is the magnitude of the impact of domestic political institution on leaders' survival probabilities. Regardless of the status of the economy, and regardless of their performance in the international arena, Autocratic leaders enjoy a level of security in office that is not matched by any other types of leaders. Authoritarian leaders have about a $73 \%$ chance of surviving in office one year or more, about a $55 \%$ probability of surviving at least 3 years, and a $22.5 \%$ probability of staying in power at least 10 years. Leaders of Mixed regimes and of Democracies cannot count on such long horizons: for them, the chances of staying in power at least one year range from about $7.8 \%$ to $15.5 \%$. The probability of surviving five years or more drops to even smaller percentages.

These probabilities are only marginally affected by economic conditions. Regardless whether the economy expands or contracts, leaders' chances of remaining in office change by no more than a few percentage points. Even an impressive economic boom in four consecutive years produces only minor tenure benefits. But if good economic performance is not substantially rewarded, neither is bad economic performance harshly punished. Let us consider democratic leaders (parliamentary and presidential, respectively), that is, leaders who 
TABle 3 Survival Probabilities ${ }^{a}$

\begin{tabular}{|c|c|c|c|c|c|c|c|c|c|}
\hline & \multicolumn{3}{|c|}{ Economy } & \multicolumn{3}{|c|}{ Chall. in Crisis 1st Yr. } & \multicolumn{3}{|c|}{ Chall. in War 1st Yr. } \\
\hline & Baseline & Good & Poor & Victory & Defeat & Draw & Victory & Defeat & Draw \\
\hline \multicolumn{10}{|l|}{ Autocracy } \\
\hline $\operatorname{Pr}(T>1 y r)$. & 0.730 & 0.738 & 0.722 & 0.888 & 0.885 & 0.888 & 0.876 & 0.865 & 0.876 \\
\hline $\operatorname{Pr}(T>3$ yrs. $)$ & 0.549 & 0.565 & 0.535 & 0.819 & 0.548 & 0.814 & 0.763 & 0.227 & 0.806 \\
\hline $\operatorname{Pr}(T>5$ yrs. $)$ & 0.390 & 0.410 & 0.372 & 0.644 & 0.334 & 0.635 & 0.567 & 0.114 & 0.634 \\
\hline $\operatorname{Pr}(T>10$ yrs. $)$ & 0.225 & 0.239 & 0.213 & 0.412 & 0.168 & 0.402 & 0.341 & 0.050 & 0.405 \\
\hline \multicolumn{10}{|l|}{ Mixed regime } \\
\hline $\operatorname{Pr}(T>1 y r)$. & 0.078 & 0.086 & 0.071 & 0.381 & 0.379 & 0.381 & 0.356 & 0.352 & 0.355 \\
\hline $\operatorname{Pr}(T>3$ yrs. $)$ & 0.034 & 0.039 & 0.029 & 0.229 & 0.155 & 0.245 & 0.292 & 0.105 & 0.244 \\
\hline $\operatorname{Pr}(T>5$ yrs. $)$ & 0.017 & 0.021 & 0.014 & 0.117 & 0.067 & 0.130 & 0.187 & 0.043 & 0.137 \\
\hline $\operatorname{Pr}(T>10$ yrs. $)$ & 0.007 & 0.009 & 0.006 & 0.050 & 0.026 & 0.057 & 0.097 & 0.016 & 0.063 \\
\hline \multicolumn{10}{|l|}{ Parl. democracy } \\
\hline $\operatorname{Pr}(T>1 y r)$. & 0.097 & 0.106 & 0.089 & 0.413 & 0.413 & 0.413 & 0.379 & 0.377 & 0.378 \\
\hline $\operatorname{Pr}(T>3$ yrs. $)$ & 0.023 & 0.027 & 0.019 & 0.134 & 0.133 & 0.140 & 0.158 & 0.096 & 0.105 \\
\hline $\operatorname{Pr}(T>5$ yrs. $)$ & 0.005 & 0.007 & 0.004 & 0.027 & 0.027 & 0.029 & 0.039 & 0.018 & 0.020 \\
\hline $\operatorname{Pr}(T>10$ yrs. $)$ & 0.001 & 0.001 & 0.000 & 0.003 & 0.003 & 0.003 & 0.005 & 0.002 & 0.002 \\
\hline \multicolumn{10}{|l|}{ Pres. democracy } \\
\hline $\operatorname{Pr}(T>1 y r)$. & 0.155 & 0.167 & 0.145 & 0.494 & 0.494 & 0.494 & 0.465 & 0.462 & 0.465 \\
\hline $\operatorname{Pr}(T>3$ yrs. $)$ & 0.064 & 0.072 & 0.057 & 0.253 & 0.253 & 0.276 & 0.291 & 0.163 & 0.279 \\
\hline $\operatorname{Pr}(T>5$ yrs. $)$ & 0.028 & 0.033 & 0.024 & 0.105 & 0.105 & 0.120 & 0.138 & 0.059 & 0.129 \\
\hline $\operatorname{Pr}(T>10$ yrs. $)$ & 0.009 & 0.011 & 0.008 & 0.033 & 0.033 & 0.039 & 0.048 & 0.017 & 0.044 \\
\hline
\end{tabular}

${ }^{a}$ The Economic development and the Trade openness variables are set at their median value in the first year, and then change according to the values of the Change in Economic development and the Change in trade openness, respectively. In the six conflict scenarios, the survival probabilities are computed while setting the Involvement as challenger variable to 1 in the first year, and to 0 thereafter. The Age variable is set to its median value in the first year, and then incremented by 1 every year. The frailty term is set at its mean value of 1 . The remaining variables are set at their median values.

supposedly should be under the constant threat of domestic adversaries ready to criticize their record. A leader of a parliamentary (presidential) democracy who can boast of a good economy has about a $10.6 \%(16.7 \%)$ chance of remaining if office one year or more, a $2.7 \%(7.2 \%)$ chance of surviving three years or more, and a .7\% (3.3\%) chance of surviving in office for five years or more. But if the economy is in a recession, those probabilities drop to $8.9 \%(14.5 \%), 1.9 \%(5.7 \%)$, and $.4 \%(2.4 \%)$. Thus, a poor economic performance hardly spells doom even for democratic leaders.

International conflict has a much more pronounced effect. In the scenario we analyze, a leader is involved in a crisis or a war as challenger for his entire first year in office, and remains at peace thereafter. This simplified situation allows us to bring to the fore how the combination of the two dimensions of conflict-participation and outcomes-affects the political careers of leaders. First, conflict involvement as a challenger substantially increases the probability of surviving at least one year in office for all types of leaders. Second, once the conflict is over, outcomes have their impact. Losing substantially increases the risk of removal compared to winning or drawing, for all types of leaders and at both levels of conflict intensity.

The survival probabilities given an entire covariate path in Table 3 also show that a leader who has fought for one year and has obtained a victory or a draw enjoys survival probabilities greater than those of a leader that has remained at peace. Even a defeated leader is not worse-off in tenure terms than a leader that has remained at peace under most circumstances. In the case of crises short of war, a victorious leader has a probability of remaining in office at least three years equal to $81.9 \%$ in an Autocracy, to $22.9 \%$ in a Mixed regime, to $13.4 \%$ in a Parliamentary democracy, and to $25.3 \%$ in a Presidential democracy. In case of defeat in crisis, on the other hand, those probabilities drop substantially, but do not drop below the levels attained by leaders that have stayed at peace: the three-year-or-more survival probability is $54.8 \%$ for an Autocrat, $15.5 \%$ for a 
Mixed regime leader, $13.3 \%$ for a Parliamentary democracyleader, and $25.3 \%$ for a Presidential democracy leader. The effects of war participation and outcomes are analogous. Only an Authoritarian leader who has lost a war is more likely to lose office than an Authoritarian leader who has kept his country out of war. But if we recall that war involvement as a challenger was not significant in Model 2, then the tenure boosts generated by war participation and outcomes are subject to greater degrees of uncertainty than those generated by crises.

\section{Robustness Checks}

We run three types of robustness checks. First, we reestimate the two models distinguishing whether the draw outcomes were the result of a compromise solution to the conflict or of a stalemate, as these outcomes are again measured in Gelpi and Griesdorf (2001) and in the ICB codings. As was the case with the Draw variable which combined Compromise and Stalemate into one single category, the coefficients on the Compromise and Stalemate outcomes in a crisis or a war are statistically undistinguishable from 0 . The results on all other variables remain analogous to those reported in Table 1 and Table 2. Thus, a different measurement rule for the draw outcomes is inconsequential for our results.

Second, we assess whether the hyperbolic transformation we use to discount the effect of conflict outcomes over time unduly affects our own results. We, therefore, estimate two alternative specifications of Model 1 and Model 2 in which we measure conflict outcomes with dummy indicators coded as 1 in the last year the conflict was waged and for the following four years, or until there is a change in leadership. We again find that losing a crisis or a war is associated with a statistically significant increase in the risk of office removal, while victory and draws do not alter leaders' tenure prospects. When we differentiate among regime types, we find that for leaders of autocracies and mixed regimes defeat in war reduces tenure, as we found in the original specification of Model 2. For democratic leaders, defeat is again insignificant. With respect to crisis outcomes, we replicate our previous finding that defeat reduces leaders' tenure in mixed regimes and in autocracies, but is inconsequential for democratic leaders. We no longer find a tenure reward for autocratic leaders who win or obtain a draw in a crisis, while the coefficients on crisis draws for leaders of parliamentary democracies and on crisis victories for leaders of presidential democracies are positive and close to statistical significance. As before, the combined tenure of victorious and defeated leaders is not lower after a war than after a crisis in both models. Overall, then, even with an alternative measurement of conflict outcomes, we fail to find evidence in support of hypotheses H.1 and H.2.

Finally, we investigate whether the higher likelihood of removal from office after a defeat in a crisis or a war is associated with any type of opponents. To this effect, we reestimate Model 1 and Model 2 by replacing the "old" Defeat variables with variables that distinguish whether the defeat occurred at the hand of an Autocratic leader, a Mixed regime leader, or a Democratic leader. ${ }^{15}$ We find that in the case of crisis, Defeat is more likely to lead to a leadership change if the opponent was an Autocrat ( $b_{\text {Lose crisis against Aut. }}=0.633, \mathrm{p}=0.025$ ) or a Democratic leader ( $b_{\text {Lose crisis against Dem. }}=0.557, \mathrm{p}=0.087$, while losing a crisis against a Mixed regime leader has no tenure consequences. In the case of war, Defeat against an Authoritarian leader is associated with reduced chances of remaining in power $\left(b_{\text {Lose war against Aut. }}=0.943, \mathrm{p}=\right.$ 0.002), while defeats against Mixed regime and Democratic leaders do not exert a statistically significant impact on tenure. Thus, our results indicate that losing against a Democratic leader does not necessarily put into motion processes leading to leadership change.

In replicating the results of Model 2, we find that Democratic leaders lost wars against Authoritarian leaders only (and primarily against Hitler in World War II), and that no Mixed regime leader ever lost against another Mixed regime leader. The impact of defeat in war on leaders' tenure is pronounced for Authoritarian leaders and Mixed regime leaders, as we found in Model 2. For both types of leaders, losing against an Autocrat significantly reduces their tenure chances, but losing against a Democratic leader is marginally significant only for Autocrats ( $\left.b_{\text {Aut. } \times \text { Lose war against Dem. }}=1.501, \mathrm{p}=0.078\right)$.

\section{Conclusions}

We have provided the broadest examination to date of the factors that affect the tenure of leaders. We found that domestic political institutions have a very large effect on the tenure of leaders while, perhaps surprisingly, economic performance has a relatively small effect. We focused in particular on how international conflict affects the tenure of leaders. We found that leaders do not systematically face a higher hazard of losing office after wars than after crises. This implies that for the contending leaders war is not negative-sum and not ex post inefficient. And if war is not ex post inefficient then mechanisms other than private information with incentives to misrepresent,

\footnotetext{
${ }^{15}$ We do not differentiate between Parliamentary or Presidential democratic leaders to avoid create categories with too few events.
} 
commitment problems, and issue indivisibility become necessary to explain war. From a modeling perspective, this seems to suggest that explanatory models that focus on the conflicting preferences of leaders and constituents should be given more attention (Bueno de Mesquita and Siverson 1995; Bueno de Mesquita et al. 2001; Schultz 2001).

The finding that war is not negative-sum for contending leaders does not mean that war is costless for individual leaders. We found that defeat is indeed costly for leaders of autocracies and mixed regimes, while victory in war does not bring benefits. These findings raise the question why office-seeking leaders would risk war, since there does not seem to be a tenure-related upside. Our findings indicate how important it is to be able to identify the factors that make a conflict worth pursuing from the perspective of an office-seeking political leader. What counts as a "popular" conflict is a question that emerges directly from our analysis, and which previous research has not given adequate treatment. Thus, our results might raise as many questions as they answer. But by questioning the central assumption of much of the rationalist conflict literature, we have opened new avenues for research.

\section{Appendix Explanatory Variables}

Regime Type. We measure domestic regime type using three dummy indicators that identify Mixed regimes, Parliamentary democracies, and Presidential democracies. Autocracies are the excluded baseline category. We code these dummy variables using the Polity IV's (2000) 21point scale: countries scoring 7 or higher are coded as Democracies, countries scoring between -6 and 6 are coded as Mixed regimes. The residual category, then, includes the regimes scoring -7 or less, which can be labeled as Autocracies (Jagger and Gurr 1995, 474). The regime scores for the countries experiencing periods of interregnum, or transition-i.e., those that are coded as -77 and -88-are converted into conventional Polity scores using the rules detailed by Monty Marshall, Director of the Polity IV project: cases of interregnum are converted to a Polity score of 0 ; cases of transition are prorated across the span of the transition. The cases of foreign interruption (Polity IV's score of -66) are excluded from the data set. ${ }^{16}$ In line with the coding rule developed by Chiozza and Goemans (2003), we code all the leaders who

\footnotetext{
${ }^{16}$ These conversion rules can be found at http://www.cidcm.umd. edu/inscr/polity/convert.htm.
}

experienced-or enacted-a regime change during their office tenure by attributing them the regime score they had for a longer period of time in the year of the regime transition.

We then distinguish between Parliamentary and Presidential democracies by a dummy variable indicator, taken from the ACLP data set of Przeworski et al. (2000) for the period 1950-1990, and recorded for the remaining periods from Cook and Paxton (1998), Derbyshire and Derbyshire (1996) and the Encyclopedia Britannica. We folded the ACLP category of Mixed democracy into the Presidential democracy category because nonparliamentary democracies can plausibly be argued to be presidential democracies for International Relations purposes, since in these systems the president typically retains significant authority in foreign affairs.

Economic development. We measure this variable using the logarithm of the levels of energy consumption per capita in any given year (Bollen 1979). Data are taken from the Correlates of War (COW) capability data set available in Bennett and Stam's (2000) EUGene (version 2.40) program for the years from 1919 to 1992, and from the United Nations' Energy Statistics Yearbook (various years) for the subsequent periods. Some additional data are taken from the World Bank's World Development Indicators-WDI Online (available at http://devdata.worldbank.org/dataonline/). ${ }^{17}$

Change in economic development. This variable measures the yearly change in the levels of economic development. It is computed as the difference between the logarithm of energy consumption per capita in year $t$ and in year $t-1$, multiplied by 100 .

Trade openness. We measure this variable using the level of total annual trade, and we standardize it by using the level of energy consumption in a country, where energy consumption serves as a proxy for a country's level of economic activity. We take the logarithm of the resulting quantity. Total trade is measured as the sum of the state's total imports plus total exports. Data are taken primarily from Barbieri (2002) for the periods until 1947, and from the International Monetary Fund's International Finanacial Statistics (available at http://www.imf.org/external/pubind.htm) for the years from 1948 onwards. We fill in missing values using

\footnotetext{
${ }^{17}$ The World Bank energy consumption data are measured in $\mathrm{kg}$ of oil equivalent per capita. We converted this measure into tons of coal-equivalent per capita units, in accordance with the COW and United Nations' data, using the rate of conversion indicated in the United Nations' Energy Statistics Yearbook 1995, pp. xxv. Data for Taiwan for the period 1971-1996 are taken from the IEA data available in the OECD Statistical Compendium - CD Rom (1998).
} 
the data in Gleditsch (2002) and in the World Bank's World Development Indicators_WDI Online (available at http://devdata.worldbank.org/dataonline/).

Change in trade openness. This variable measures the yearly change in the levels of trade openness. It is computed as the difference between the logarithm of trade openness in year $t$ and in year $t-1$, multiplied by 100 .

Population. This variable measures the logarithm of the total population in each country in any given year. Data are taken from the COW capability data set available in Bennett and Stam's (2000) EUGene (version 2.40), from Mitchell's (1998a,b,c) International Historical Statistics, and from the World Bank's World Development Indicators-WDI Online (available at http://devdata. worldbank.org/dataonline/).

Civil war. This is a dummy variable that takes on the value of 1 whenever a leader is in office during a civil war and 0 otherwise. Data are taken from the latest version of the COW Intra-State War data set from Sarkees (2000) for the years until 1997. For 1998 and 1999, civil war data are taken from Fearon and Laitin (2003).

Age. This variable measures leaders' age. Data are obtained from Bienen and van de Walle (1991), Lentz (1994), Lentz (1999), the http://www.rulers.org web page, the http://www.worldstatesmen.org web page, and Encyclopedia Britannica.

Times in office. This is a count variable that measures the number of times a leader has previously ruled a country. It is equal to 0 in the first period in office.

Conflict involvement. See the description of these variables in the text on page 608 .

Conflict outcomes. See the description of these variables in the text on page 608 .

\section{References}

Allison, Paul D. 2002. Missing Data. Sage University Papers Series on Quantitative Applications in the Social Sciences, 07136. Thousand Oaks, CA: Sage.

Barbieri, Katherine. 2002. The Liberal Illusion: Does Trade Promote Peace? Ann Arbor: University of Michigan Press.

Bennett, D. Scott, and Allan C. Stam. 2000. "EUGene: A Conceptual Manual.” International Interactions 26(2):179-204.

Bienen, Henry, and Nicholas van de Walle. 1991. Of Time and Power: Leadership Duration in the Modern World. Stanford: Stanford University Press.

Bollen, Kenneth A. 1979. "Political Democracy and the Timing of Development." American Sociological Review 44(4):57287.
Box-Steffensmeier, Janet M., Dan Reiter, and Christopher J. W. Zorn. 2003. "Nonproportional Hazards and Event History Analysis in International Relations." Journal of Conflict Resolution 47(1):33-53.

Brecher, Michael, and Jonathan Wilkenfeld. 1997. A Study of Crisis. Ann Arbor: University of Michigan Press.

Bueno de Mesquita, Bruce, Alastair Smith, Randolph M. Siverson, and James D. Morrow. 2003. The Logic of Political Survival. Cambridge: MIT Press.

Bueno de Mesquita, Bruce, James D. Morrow, Randolph M. Siverson, and Alastair Smith. 1999. "An Institutional Explanation of the Democratic Peace." American Political Science Review 93(4):791-807.

Bueno de Mesquita, Bruce, James D. Morrow, Randolph M. Siverson, and Alastair Smith. 2001. Political Survival and International Conflict. In War in a Changing World, ed. Zeev Maoz and Azar Gat. Ann Arbor: University of Michigan Press, pp. 183-206.

Bueno de Mesquita, Bruce, and Randolph M. Siverson. 1995. "War and the Survival of Political Leaders: A Comparative Study of Regime Types and Political Accountability." American Political Science Review 89(4):841-55.

Cheibub, José Antonio, and Adam Przeworksi. 1999. Democracy, Elections, and Accountability for Economic Outcomes. In Democracy, Accountability, and Representation, ed. Adam Przeworksi, Susan C. Stokes, and Bernard Manin. Cambridge: Cambridge University Press, pp. 222-49.

Chiozza, Giacomo, and H. E. Goemans. 2003. "Peace through Insecurity: Tenure and International Conflict." Journal of Conflict Resolution 47(4):443-67.

Cook, Chris, and John Paxton. 1998. European Political Facts, 1900-1996. New York: St. Martin's Press.

Copeland, Dale C. 2000. The Origins of Major War. Ithaca: Cornell University Press.

Correlates of War 2 Project. 2003. State System Membership List, v2002.1. Available at http://cow2.la.psu.edu.

Derbyshire, J. Denis, and Ian Derbyshire. 1996. Political Systems of the World. New York: St. Martin's Press.

Downs, Anthony. 1957. An Economic Theory of Democracy. New York: Harpers and Collins.

Downs, George, and David M. Rocke. 1994. "Conflict, Agency and Gambling for Resurrection: The Principal-Agent Problem Goes to War." American Journal of Political Science $38(2): 362-80$.

Fearon, James D. 1995. "Rationalist Explanations for War.” International Organization 49(3):379-414.

Fearon, James D., and David D. Laitin. 2003. "Ethnicity, Insurgency, and Civil War." American Political Science Review 97(1):75-90.

Friedrich, Robert J. 1982. "In Defense of Multiplicative Terms in Multiple Regression Equations.” American Journal of Political Science 26(4):797-833.

Gaubatz, Kurt Taylor. 1991. "Election Cycles and War.” Journal of Conflict Resolution 35(2):211-44.

Gelpi, Christopher. 1997. "Democratic Diversions: Government Structure and the Externalization of Domestic Conflict." Journal of Conflict Resolution 41(2):255-82.

Gelpi, Christopher, and Michael Griesdorf. 2001. "Winners or Losers? Democracies in International Crisis, 1918-94." American Political Science Review 95(3):633-47. 
Gill, Jeff. 2001. Interpreting Interactions and Interaction Hierarchies in Generalized Linear Models: Issues and Applications. Presented at the 2001 Annual Meeting of the American Political Science Association, San Francisco.

Gleditsch, Kristian S. 2002. "Expanded Trade and GDP Data." Journal of Conflict Resolution 46(5):712-24.

Hess, Gregory D., and Athanasios Orphanides. 1995. "War Politics: An Economic, Rational-Voter Framework." American Economic Review 85(4):828-46.

International Crisis Behavior Project. 2003. ICB Version 4 (1918-2001). Available at http://www.icbnet.org/.

Jagger, Keith, and Ted Robert Gurr. 1995. "Tracking Democracy's Third Wave with the Polity III Data.” Journal of Peace Research 32(4):469-82.

King, Gary, James Honaker, Anne Joseph, and Kenneth Scheve. 2001. "Analyzing Incomplete Political Science Data: An Alternative Algorithm for Multiple Imputation." American Political Science Review 95(1):49-69.

Leeds, Brett Ashley, and David R. Davis. 1997. "Domestic Political Vulnerability and International Disputes." Journal of Conflict Resolution 41(6):814-34.

Lentz, Harris M. 1994. Heads of States and Governments: A Worldwide Encyclopedia of Over 2,300 Leaders, 1945 through 1992. Jefferson, NC: McFarland.

Lentz, Harris M. 1999. Encyclopedia of Heads of States and Governments, 1900 through 1945. Jefferson, NC: McFarland.

Li, Kim-Hung, Xiao-Li Meng, T. E. Raghunathan, and Donald B. Rubin. 1991. "Significance Levels from Repeated $p$-Values with Multiply-Imputed Data.” Statistica Sinica 1(1):6592.

Linz, Juan J. 1994. Presidential or Parliamentary Democracy: Does It Make a Difference? In The Failure of Presidential Democracy, ed. Juan J. Linz and Arturo Valenzuela. Baltimore: Johns Hopkins University Press, pp. 3-87.

Mitchell, B. R. 1998a. International Historical Statistics: Africa, Asia \& Oceania, 1750-1993. London: Macmillan.

Mitchell, B. R. 1998b. International Historical Statistics: The Americas, 1750-1993. London: Macmillan.
Mitchell, B. R. 1998c. International Historical Statistics: Europe, 1750-1993. London: Macmillan.

Petersen, Trond. 1986. "Fitting Parametric Survival Models with Time-Dependent Covariates." Applied Statistics 35(3):28188.

Petersen, Trond. 1991. "The Statistical Analysis of Event Histories." Sociological Methods and Research 19(3):270-323.

Polity IV Project. 2000. Polity IV Dataset, version p4v2000. College Park: Center for International Development and Conflict Management, University of Maryland.

Przeworski, Adam, Michael E. Alvarez, José Antonio Cheibub, and Fernando Limongi. 2000. Democracy and Development: Political Institutions and Well-Being in the World, 1950-1990. Cambridge: Cambridge University Press.

Reiter, Dan, and Allan C. Stam. 2002. Democracies at War. Princeton: Princeton University Press.

Rodrik, Dani. 1998. "Why Do More Open Economies Have Bigger Governments?” Journal of Political Economy 106(5):9971032.

Rubin, Donald B. 1987. Multiple Imputation for Nonresponse in Surveys. New York: Wiley.

Rubin, Donald B., and Nathaniel Schenker. 1991. "Multiple Imputation in Health-Care Databases: An Overview and Some Applications." Statistics in Medicine 10(4):585-98.

Sarkees, Meredith Reid. 2000. "The Correlates of War Data on War: An Update to 1997." Conflict Management and Peace Science 18(1):123-44.

Schafer, Joseph L. 1997. Analysis of Incomplete Multivariate Data. New York: Chapman \& Hall.

Schultz, Kenneth A. 2001. "Looking for Audience Costs.” Journal of Conflict Resolution 45(1):32-60.

Smith, Alastair. 1998. "International Crises and Domestic Politics." American Political Science Review 92(3):623-38.

Therneau, Terry M., and Patricia M. Grambsch. 2000. Modeling Survival Data: Extending the Cox Model. New York: SpringerVerlag.

Tullock, Gordon. 1987. Autocracy. Boston: Kluwer. 